\title{
Observations on the Labelling of a Strain of Staphylococcus aureus with Phosphorus-32
}

\author{
By JUNE ROBSON \\ Kanematsu Memorial Institute, Sydney Hospital, Sydney, Australia
}

(Received 10 June 1963)

\begin{abstract}
SUMMARY
The best labelling of Staphylococcus aureus (var. pyogenes) with ${ }^{32} \mathrm{P}$ was achieved when the organisms were grown in broth containing $\mathbf{3 3} \mu \mathrm{g}$. orthophosphate $/ \mathrm{ml}$. and $150-200 \mu \mathrm{c} . / \mathrm{ml}$. ${ }^{32} \mathrm{P}$. Cocci labelled in this way were as virulent to mice as control cocci. The phosphorus content of cocci was proportional to the orthophosphate content of the medium over the range $5 \mu \mathrm{g} .-300 \mu \mathrm{g}$. $\mathrm{PO}_{4} / \mathrm{ml}$. ${ }^{32} \mathrm{P}$ was released from cocci when they were incubated with phosphate buffer and other media which did not support cell division. ${ }^{32} \mathbf{P}$ was released from labelled dividing cocci grown in nonradioactive media. About $80 \%$ of the ${ }^{32} \mathrm{P}$ was released during division; a maximum of about $\mathbf{5 5 \%}$ was released from non-dividing cocci over a similar time period. Most of the ${ }^{32} \mathrm{P}$ released from dividing cocci was present in the form of molecules non-diffusible in dialysis $(80 \%)$; most of the ${ }^{32} \mathrm{P}$ released into phosphate buffer was diffusible. Cocci deficient or rich in phosphorus were fractionated with trichloroacetic acid (TCA), ether, ethanol and perchloric acid. Cocci containing low amounts of $\mathbf{P}$ lacked ${ }^{32} \mathrm{P}$ in the fraction soluble in cold TCA, about $80 \%$ of which was orthophosphate. Cocci deficient in phosphorus incorporated ${ }^{32} \mathrm{P}$ from ${ }^{32} \mathrm{PO}_{4}$ solutions more rapidly than enriched cocci. The distributions of ${ }^{32} \mathrm{P}$ in cocci previously rich or deficient in $P$ were similar, but labelling in deficient cocci was increased in the RNA-containing fraction; and that part of the fraction soluble in hot TCA which had a barium salt insoluble at pH 4. The phosphorus level in the cells had no effect on the amount of phosphorus released into phosphate buffer solution.
\end{abstract}

\section{INTRODUCTION}

Ely (1942) labelled Staphylococcus aureus with unstated amounts of ${ }^{32} \mathrm{P}$ and Thorbecke \& Benacerraf (1959) labelled $S$. pyogenes with ${ }^{32} \mathrm{P}$ by growing the organisms in the medium containing $20 \mu \mathrm{c}$. ${ }^{32} \mathbf{P} / \mathrm{ml}$. The labelled organisms were used for tracer studies in animals and for that purpose the specific activity of the bacterium should be as high as is compatible with normal functioning of the cell. Experiments were made to discover the factors which affected ${ }^{32} \mathbf{P}$ incorporation and those conditions which gave good labelling and viable organisms. Stonier (1956) had previously labelled Agrobacterium tumefaciens with ${ }^{32} \mathrm{P}$ and studied the behaviour of the label; the following experiments were made along similar lines with $S$. aureus. 


\section{METHODS}

Strain. Staphylococcus aureus, strain 1531, isolated in Melbourne in 1957 from meninges, was used in these experiments. It has been maintained on nutrient agar under paraffin oil.

Inoculum. Cocci from a $24 \mathrm{hr}$ culture on nutrient agar were suspended in sterile distilled water (about $10^{9} \mathrm{cocci} / \mathrm{ml}$.) and 1 drop of this solution from a Pasteur pipette was used as an inoculum.

Media. The cocci were grown in nutrient broth from which orthophosphate had been removed by precipitation with ammonium molybdate. The nutrient broth contained ( $\mathrm{NaCl}, 5.0 \mathrm{~g}$., peptone, $10.0 \mathrm{~g}$., Lab. Lemco, 10.0 g., distilled water, $1000 \mathrm{ml}$.). The orthophosphate was removed by boiling the broth with $2 \mathrm{ml}$. concentrated $\mathrm{HNO}_{3}$ for $15 \mathrm{~min}$. and adding a hot, saturated solution of ammonium molybdate drop by drop until no further precipitate was obtained in the filtered broth. The medium was filtered and adjusted to $\mathrm{pH} 7 \cdot 8$ with $\mathrm{N}-\mathrm{NaOH}$. The phosphate content of the broth, determined by Briggs's (1922) method, was less than $5 \mu \mathrm{g}$. $\mathrm{PO}_{4} / \mathrm{ml}$. Untreated nutrient broth contained $\mathbf{7 0 0} \mu \mathrm{g} . \mathrm{PO}_{4} / \mathrm{ml}$. The excess ammonium molybdate was not removed from the broth and the molybdenum present, determined by the method of Sandell (1953), was $320 \mu \mathrm{g} . / \mathrm{ml}$. ${ }^{32}$ P-labelled orthophosphate (from the Commonwealth X-Ray and Radium Laboratories, Melbourne, who obtained it from Radiochemical Centre, Amersham) and $\mathrm{PO}_{4}$ as $\mathrm{Na}_{2} \mathrm{HPO}_{4}$ were added to this broth as required. The solution was dispensed in 2-3 ml. volumes into $50 \mathrm{ml}$. conical flasks and sterilized at $121^{\circ}$ for $15 \mathrm{~min}$.

Treatment of cocci. Cocci were separated from the supernatant fluid by centrifuging at $11,000 \mathrm{rev} . / \mathrm{min}$. for $30 \mathrm{~min}$. at $4^{\circ}$. Cocci were washed three times either with a physiological saline solution $(0.85 \mathrm{~g}$. NaCl$/ 100 \mathrm{ml}$.) containing $0.025 \%$ human serum albumin or with distilled water. Washing with distilled water was used when the specific activity of cocci was determined. Solutions in which cocci were suspended for ${ }^{32} \mathrm{P}$. release studies were placed in $40 \mathrm{ml}$. centrifuge tubes, previously sterilized with alcohol, and left in a $37^{\circ}$ water bath for appropriate times.

Fractionation of cocci. Cocci were frozen and thawed twice in about $1 \mathrm{ml}$. water. Phosphorus-containing compounds were fractionated according to the method of Mudd, Yoshida \& Koike (1958). Each fraction was not analysed chemically but the probable content of each was as follows:

Phosphorus compounds that were soluble in $5 \%$ trichloroacetic acid (TCA) after $1 \mathrm{hr}$ at $4^{\circ}$. Hancock (1958) showed that inorganic phosphorus and amino acids were present in a similar extract prepared from Staphylococcus aureus. Phosphorus in this solution was precipitated with barium acetate at $\mathrm{pH} 4$ and the remaining soluble phosphorus was precipitated at $\mathrm{pH} 7 \cdot 4$ with barium acetate. Metaphosphates are normally precipitated from TCA solutions at $\mathbf{p H} 4$. Metaphosphate has not been identified from $S$. aureus and the precipitate obtained in these experiments has not been definitely characterized. The phosphorus precipitated at acid pH with barium acetate (2-20\% total) has been tentatively called 'metaphosphate' since others have found metaphosphate in similar extracts of Mycobacteria (Mudd et al. $1958) ; 80-85 \%$ of the phosphorus remaining in acid solution was precipitated with barium acetate at $\mathrm{pH} 7 \cdot 4$. The remaining phosphorus compounds were not characterized. 
$\boldsymbol{P}$ compounds that were soluble in alcohol and $3+1$ alcohol + ether mixtures. Park \& Hancock (1960) showed that lipid and polypeptides were present in this extract and the phosphorus extracted was probably combined in these compounds.

$P$ compounds that were soluble in $5 \%$ TCA after 5 min. at $95^{\circ}$. Park \& Hancock (1960) showed that nucleic acids were present in this extract with virtually all the teichoic acid from the cell wall. This fraction was treated at $\mathrm{pH} 4$ with barium acetate and the precipitate obtained tentatively called 'polyphosphate', although polyphosphate was not characterized. The supernatant fluid from acid barium acetate

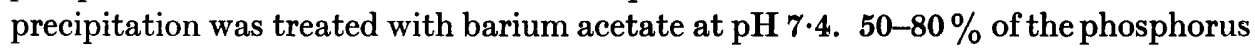
present was precipitated with this reagent. Some $\mathrm{PO}_{4}$ was probably present with organically bound phosphorus since Mudd et al. (1958) found that hydrolysis of polyphosphate occurred during extraction.

$\boldsymbol{P}$ compounds that were soluble in cold $\mathrm{N}$-perchloric acid after $24 \mathrm{hr}$. Ribonucleic acids were extracted by Mudd et al. using this technique and the phosphorus present in this extract probably represented mostly RNA phosphorus.

$P$ compounds that were soluble in $5 \%$ TCA after 15 min. at $95^{\circ}$. Deoxyribonucleic acid was extracted from mycobacteria by Mudd et al. (1958) using this technique. It seems likely from the studies of Park \& Hancock (1960) that some nucleic acid-P would also have been extracted with TCA at $95^{\circ}$ for $5 \mathrm{~min}$. The P extracted would then be less than the total $\mathbf{P}$ present in DNA.

Phosphorus which remained in the cocci after the extraction procedure described was extracted after $2 \mathrm{hr}$ hydrolysis with $\mathrm{N}-\mathrm{H}_{2} \mathrm{SO}_{4}$ at $100^{\circ}$.

Radioactivity measurements. ${ }^{32} \mathrm{P}$-containing solutions were counted in a GeigerMüller counter for liquids attached to a high-tension power supply and scaler. Appropriate corrections were applied to measurements for paralysis time, radioactive decay and counter efficiency. The specific activity of cocci was determined by drying the cocci to constant weight on a watch glass and dissolving them in $10 \mathrm{ml}$. concentrated $\mathrm{HNO}_{3}$.

Counts of viable cocci and measurements of turbidity. Viable bacterial counts were measured after the method of Miles \& Misra (1938). Optical extinctions of the bacterial suspensions were read on a Unicam SP 600 spectrophotometer at $470 \mathrm{~m} \mu$ and standardized against direct haemocytometer counts.

\section{RESULTS}

\section{Phosphate requirements and uptake}

The number of cocci harvested from broth was a maximum when $6 \mu \mathrm{g}$. $\mathrm{PO}_{4} / \mathrm{ml}$. was present. When less than this amount was added per flask the yield decreased slightly but the harvest of about $10^{8}$ cocci ml. was not increased when the phosphate was increased in $6 \mu \mathrm{g} . / \mathrm{ml}$. increments to $36 \mu \mathrm{g} . / \mathrm{ml}$. Viability of the cocci grown in broth containing less than $6 \mu \mathrm{g} . / \mathrm{ml}$. was poorer, $7 \cdot 6 \%$ total cocci compared with $\mathbf{9} \cdot \mathbf{3} \%$ when cocci were grown in broth containing $\mathrm{PO}_{4}$ in excess of that amount. An aqueous suspension of cocci from a nutrient agar slope required only small amounts of $\mathrm{PO}_{4}$ to increase to about $10^{8}$ cocci $\mathrm{ml}$.

Experiments were made to discover whether the cocci would accumulate more phosphorus than the minimum amount required for growth and viability. The incorporation of $\mathrm{PO}_{4}$ into the cocci was studied using tracer amounts of ${ }^{32} \mathrm{PO}_{4}$ added 
with orthophosphate. Cocci were grown in media which contained 70-450 $\mu \mathrm{g.}{ }^{32} \mathrm{PO}_{4} /$ ml. (Fig. 1). The cocci appeared to be saturated with phosphorus after growing in a medium containing $300 \mu \mathrm{g} . / \mathrm{ml}$. The percentage of ${ }^{32} \mathrm{P}$ in the cocci remained at 4-5\% of that present in the broth when 70-300 $\mu \mathrm{g} . \mathrm{PO}_{4} / \mathrm{ml}$. were present, but decreased to about $3 \%$ at higher concentrations. The cocci were able to accumulate more phosphorus than was necessary for normal growth and viability. The nutrient agar used to grow cocci for inoculation contained $700 \mu \mathrm{g} . \mathrm{PO}_{4} / \mathrm{ml}$. and the inoculum cocci probably contained reserve phosphorus. This may have enabled them to grow in broth containing less than $6 \mu \mathrm{g}$. $\mathrm{PO}_{4} / \mathrm{ml}$.

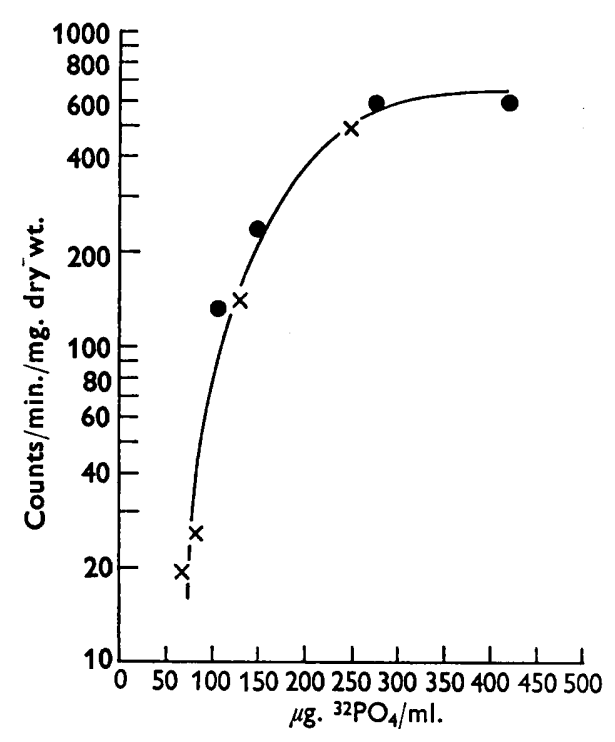

Fig. 1. The relationship between cell ${ }^{32} \mathrm{P}$ and concentration of ${ }^{32} \mathrm{PO}_{4}$ in the medium.

The effect of the specific activity of ${ }^{32} \mathrm{PO}_{4}$ on growth and viability

The following experiments were made to discover the maximum amount of ${ }^{32} \mathbf{P}$ a coccus could contain without detriment to viability and growth and also the amount of ${ }^{32} \mathrm{PO}_{4}$ necessary in the broth to achieve this labelling. The total number of cocci $/ \mathrm{ml}$. and the total number viable were compared in cultures which contained $\mathrm{PO}_{4}$ only and ${ }^{32} \mathrm{PO}_{4}$ with various specific activities. Replicate cultures contained ${ }^{32} \mathrm{PO}_{4}$ with specific activities of 3.7 $\mu \mathrm{c} . / \mu \mathrm{g} . ; 5 \cdot 5 \mu \mathrm{c} . / \mu \mathrm{g} ., 13 \cdot 8 \mu \mathrm{c} . / \mu \mathrm{g} ., 1 \mathrm{mc} . / \mu \mathrm{g}$. and $67 \mu \mathrm{g}$., $33 \mu \mathrm{g}$., $18 \mu \mathrm{g}$., $0 \cdot 25 \mu \mathrm{g}$. $\mathrm{PO}_{4} / \mathrm{ml}$. respectively. Control cultures contained the same amount of $\mathbf{P O}_{4}$. No growth occurred in the culture containing $250 \mu \mathrm{c} .{ }^{32} \mathrm{P}$ and $0.25 \mu \mathrm{g} . \mathrm{PO}_{4} / \mathrm{ml}$; the control culture contained $2 \cdot 1 \times 10^{8}$ cocci about $8 \%$ of which were viable. Growth of cocci was $60 \%$ that of the control culture when the specific activity of the ${ }^{32} \mathrm{PO}_{4}$ was $13 \cdot 8 \mu \mathrm{c} . / \mu \mathrm{g}$. and the viability was decreased from $0 \cdot 3 \%$ (control) of total cocci to $\mathbf{0 . 0 0 0 3} \%$. Growth was about $25 \%$ of the control when the specific activity was $5.5 \mu \mathrm{c} . / \mu \mathrm{g}$. but viability was unaffected; $\mathbf{0} \cdot 23 \%$ of total cocci were viable compared with $0 \cdot 1 \%$ (controls). Growth and viability were not affected when the specific activity of the ${ }^{32} \mathrm{PO}_{4}$ was $3 \cdot 7 \mu \mathrm{c} / \mu \mathrm{g}$. The total number of cocci was $8 \times 10^{9}$ in control and experimental flasks and the number viable was 
$0.5 \%$ total (control), $0.6 \%$ total $\left({ }^{32} \mathrm{P}\right.$-containing broth). The greatest ${ }^{32} \mathrm{PO}_{4}$ uptake, $44 \%$ of that present in the broth, occurred when the specific activity of the ${ }^{32} \mathrm{PO}_{4}$ was $13.8 \mu \mathrm{c} . / \mu \mathrm{g}$. and $18 \mu \mathrm{g}$. $\mathrm{PO}_{4} / \mathrm{ml}$. were present. However, these cells had a low viability $(0.0003 \%$ of total cells) and were thus unsatisfactory for tracer experiments in animals. When the specific activity of the ${ }^{32} \mathrm{PO}_{4}$ was $5.5 \mu \mathrm{c}$. $/ \mu \mathrm{g}$. with $33 \mu \mathrm{g} . \mathrm{PO}_{4} / \mathrm{ml}$. present in the medium, $14 \%$ of the ${ }^{32} \mathrm{PO}_{4}$ present in the broth was incorporated into the cocci. Cocci grown under these conditions were as viable as control cocci and were as virulent in mice as non-radioactive cocci. They had a specific activity of $3 \cdot 3 \times 10^{-8} \mu \mathrm{c} .{ }^{32} \mathrm{P} /$ coccus, which was similar to the specific activity of the cocci with reduced viability from cultures containing $13 \cdot 8 \mu \mathrm{c} / \mu \mathrm{g}$. ${ }^{32} \mathrm{PO}_{4}$. The specific activity of cocci from cultures containing $3 \cdot 7 \mu \mathrm{c} . / \mu \mathrm{g} . \mathbf{P O}_{4}$ and $67 \mu \mathrm{g}$. $\mathrm{PO}_{4} / \mathrm{ml}$. was $2 \cdot 4 \times 10^{-9} \mu \mathrm{c}$. $/$ coccus and only $4 \%$ of the ${ }^{32} \mathrm{PO}_{4}$ in the broth was incorporated in the cocci. Cocci labelled under these conditions were not used for tracer experiments in animals.

Distribution of ${ }^{32} P$ in coccal fractions after uptake during growth

Cocci were labelled with ${ }^{32} \mathrm{P}$ by growing them in broth containing 18-500 $\mu \mathrm{g}$. $\mathrm{PO}_{4} / \mathrm{ml}$. and $150-200 \mu \mathrm{c} .{ }^{32} \mathrm{P} / \mathrm{ml}$. They were washed three times with a solution of $0.025 \%$ albumin in $0.85 \% \mathrm{NaCl}$. Cocci washed in this way lost about $0 \cdot 2-0.3 \%$ of their ${ }^{32} \mathrm{P}$ if they were suspended in the albumin-saline solution for $1 \mathrm{hr}$. They lost about $50 \%$ of their ${ }^{32} \mathrm{P}$ content when they were suspended in $\mathrm{PO}_{4}$ buffer for $1 \mathrm{hr}$. Therefore, albumin saline was assumed to be a safe washing medium for cocci later

\section{Table 1. Fractionation of cocci deficient and rich in phosphorus to show the distribution of ${ }^{\mathbf{3 2} P}$ under these conditions}

The relative amounts of phosphorus in the cocci were controlled by the phosphate content of the broth.

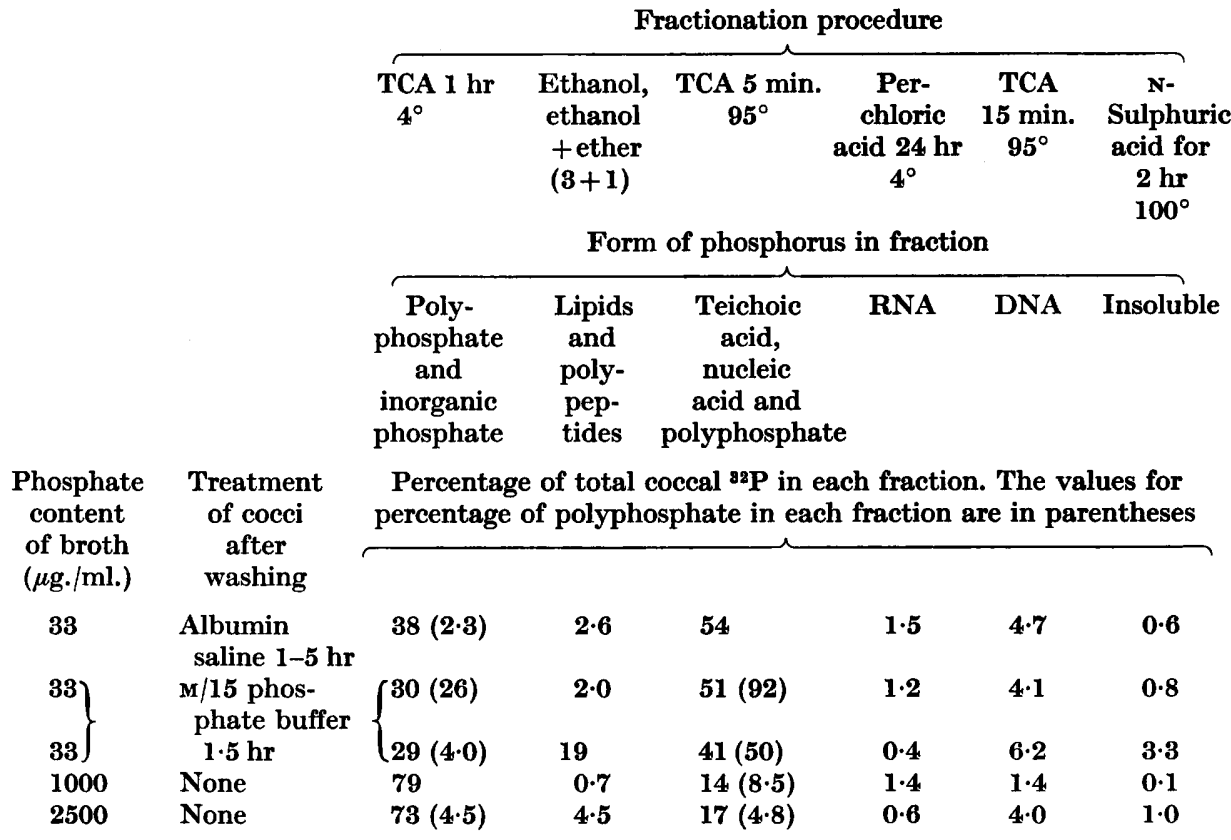


fractionated. Cocci grown in media with different $\mathrm{PO}_{4}$ contents were analysed to discover the distribution of ${ }^{32} \mathrm{P}$ in the various cell compounds. Previous experiments showed that a coccus was saturated with phosphorus when it was grown in a medium containing more than $400 \mu \mathrm{g}$. $\mathrm{PO}_{4} / \mathrm{ml}$. The proportion of ${ }^{32} \mathrm{P}$ in the various fractions was influenced by the available $\mathrm{PO}_{4}$ (Table 1). When small amounts were available the hot TCA fraction contained the most; when $1000 \mu \mathrm{g}$. $\mathrm{PO}_{4}$ or more were present in the medium the cold TCA fraction contained most ${ }^{32}$. This would indicate that the hot TCA fraction was preferentially labelled and that when adequate phosphate was available then the cold TCA fraction was replenished with ${ }^{32} \mathrm{P}$. This agrees with Albaum's et al. (1952) studies in plant seeds, when phosphorus was incorporated preferentially in certain compounds in states of phosphorus deficiency and appeared in greater amounts in other compounds in normal embryos. In phosphorus-rich cocci most of the ${ }^{52} \mathrm{P}$ was present in the inorganic fraction (cold TCA). Phosphorusrich cocci contained proportionally less ${ }^{32} \mathrm{P}$ in the 'polyphosphate' fractions, especially in the acid-insoluble 'polyphosphate' fractions. In one experiment placing cocci in phosphate buffer caused an increase in ${ }^{32} \mathrm{P}$ in 'polyphosphate' but not in another (Table 1). Polyphosphate has been shown to increase and decrease according to the division cycle of the cocci (Sall et al. 1958) and may be influenced only at certain stages by immersion in phosphate buffer. Since the percentage of 'polyphosphate'-32P did not increase in phosphorus-rich cocci it does not appear to serve as a $\mathrm{PO}_{4}$ reservoir.

\section{The uptake of ${ }^{32} \mathrm{PO}_{4}$ by non-dividing cocci and the distribution of ${ }^{32} \mathrm{P}$ in coccal fractions under these conditions}

Mitchell \& Moyle (1953) found that ${ }^{32} \mathrm{P}$ was taken up by non-dividing Staphylococcus aureus and that $91 \%$ of the ${ }^{32} \mathrm{P}$ appeared in the inorganic fraction. Since Mitchell \& Moyle's growth medium was not treated to remove orthophosphate their cocci were probably not phosphorus deficient. Experiments were made to discover the effect of the concentration of coccal $\mathrm{P}$ on ${ }^{32} \mathrm{PO}_{4}$ uptake. Cocci after these experiments were washed with water at $4^{\circ}$ since Hancock (1958) showed that washing with water did not cause a large release of intracellular compounds. The specific activity of a portion of the cocci was determined after washing with water.

Staphylococcus aureus when suspended in a phosphate solution containing carrierfree ${ }^{32} \mathrm{PO}_{4}$ incorporated ${ }^{32} \mathrm{P}$ into all coccal fractions. The rate at which ${ }^{32} \mathrm{PO}_{4}$ entered the cocci increased with decreasing cocci $\mathbf{P}$ (Table 2). When maximal ${ }^{32} \mathrm{PO}_{4}$ concentration was reached the ${ }^{32} \mathrm{P}$ in the cocci then decreased; how long absorption proceeded before release occurred was related to the concentration of ${ }^{32} \mathrm{PO}_{4} / \mathrm{ml}$. in the surrounding medium and the level of $\mathbf{P}$ in the cocci.

Cocci were fractionated after $1 \mathrm{hr}$ in the suspending medium; excess medium was removed by washing twice with water. ${ }^{32} \mathrm{P}$ entered all the cell fractions, but most of it was present in the inorganic fraction soluble in cold TCA (Table 3). These observations are similar to those of Mitchell \& Moyle (1953) but the rate of phosphate exchange depended on the concentration of cell $\mathbf{P}$. The RNA phosphorus fraction was enriched more in the cocci which contained the smallest amount of $\mathbf{P}$ originally. 
Table 2. The relationship between the coccal phosphorus content and the uptake of ${ }^{32} \mathrm{PO}_{4}$ from non-nutrient solutions for phosphorus-deficient cocci

The concentration of coccal phosphorus was related to the phosphate content of the culture fluid. See Fig. 1.

\begin{tabular}{|c|c|c|c|}
\hline \multirow[b]{2}{*}{$\begin{array}{l}\text { Phosphate } \\
\text { concentration } \\
\text { of broth } \\
(\mu \mathrm{g} / \mathrm{ml} .)\end{array}$} & \multicolumn{3}{|c|}{$\begin{array}{c}\text { Uptake of }{ }^{32} \mathrm{P} \text { by cocci from a non-nutrient } \\
\text { solution of }{ }^{32} \mathrm{PO}_{4}\end{array}$} \\
\hline & $\begin{array}{l}\text { Concentration } \\
\text { of }{ }^{{ }^{2}} \mathbf{P}(\mu \mathrm{c} . / \mathrm{ml} .)\end{array}$ & $\begin{array}{c}\text { Period of } \\
\text { suspension } \\
\text { in }{ }^{32} \mathbf{P} \\
\text { solution } \\
\text { (min.) }\end{array}$ & $\begin{array}{c}\text { s2P uptake by cocci } \\
\text { (counts/min./mg. } \\
\text { cocci } \\
\text { dry wt.) }\end{array}$ \\
\hline$<1.0$ & 0.01 & 15 & $9 \cdot 65 \times 10^{2}$ \\
\hline$<1 \cdot 0$ & 0.01 & 60 & $1.73 \times 10^{8}$ \\
\hline$<1.0$ & $5 \cdot 5$ & 15 & $8.30 \times 10^{5}$ \\
\hline$<1.0$ & $5 \cdot 5$ & 60 & $3.83 \times 10^{5}$ \\
\hline 16.5 & 0.01 & 15 & $1.85 \times 10^{2}$ \\
\hline 16.5 & 0.01 & 60 & $1.83 \times 10^{2}$ \\
\hline 16.5 & $5 \cdot 5$ & 15 & $8.66 \times 10^{4}$ \\
\hline 16.5 & $5 \cdot 5$ & 60 & $4.54 \times 10^{4}$ \\
\hline 33 & 0.01 & 15 & 58 \\
\hline 33 & 0.01 & 60 & $1.27 \times 10^{2}$ \\
\hline 33 & $5 \cdot 5$ & 15 & $3.07 \times 10^{4}$ \\
\hline 33 & $5 \cdot 5$ & 60 & $1.26 \times 10^{4}$ \\
\hline
\end{tabular}

The addition of $10 \mu \mathrm{g} . / \mathrm{ml}$. of phosphate to the $0.01 \mu \mathrm{c} . / \mathrm{ml}$. ${ }^{32} \mathrm{PO}_{4}$ solution resulted in the coccal 32P content reaching a maximum in $15 \mathrm{~min}$.

Table 3. The fractionation of cocci to obtain the distribution of ${ }^{\mathbf{3 2} P}$ taken up by non-dividing cocci containing different amounts of phosphorus

The ${ }^{32} \mathbf{P}$ incorporated by the cocci was proportional to the coccal phosphorus content. The fractionation procedure is as given in Table 1 .

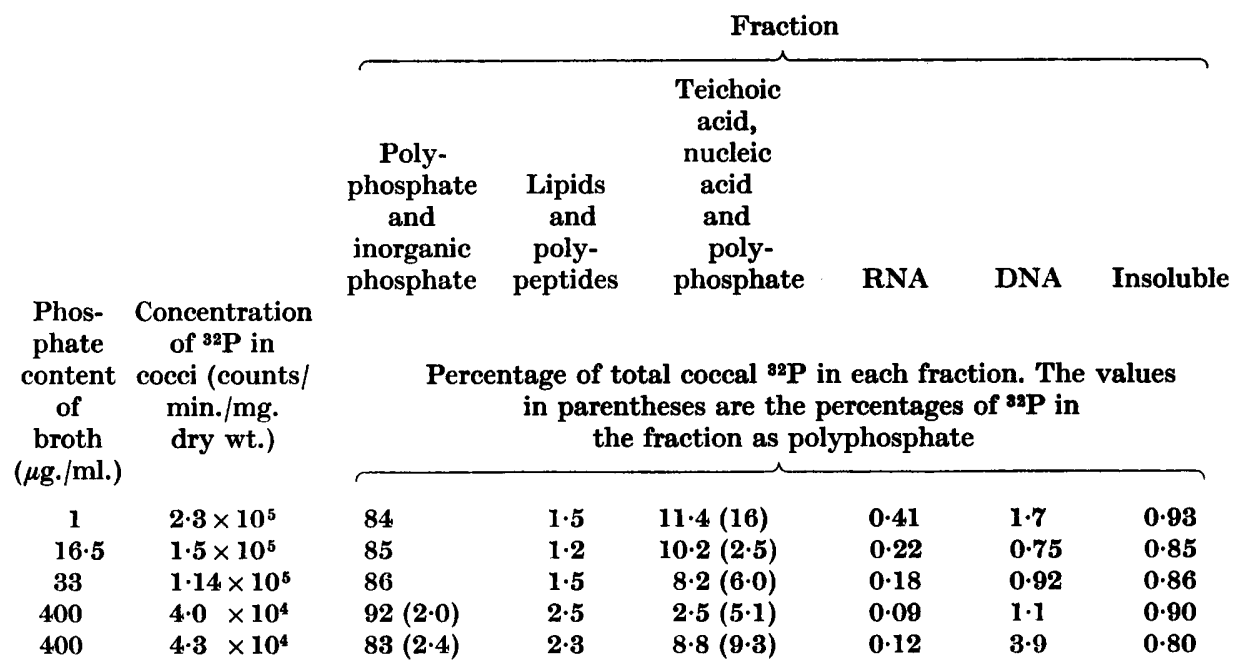




\section{Release of ${ }^{32} P$ from the cocci}

(a) Release in solutions not supporting growth

Cocci placed in $\mathrm{M} / 15$ phosphate buffer for $1 \frac{1}{2} \mathrm{hr}$ at $37^{\circ}$ released between 13 and $30 \%$ of the ${ }^{32} \mathrm{P}$ they contained. When the cocci were washed and resuspended in $\mathrm{M} / \mathbf{1 5}$ phosphate buffer they lost about 5-20\% more of the ${ }^{32} \mathrm{P}$ they contained. This subsequent release of ${ }^{32} \mathrm{P}$ after $1 \frac{1}{2} \mathrm{hr}$ in $\mathrm{M} / 15$ phosphate buffer was not prevented by suspending in $2 \%$ glucose solution, borate buffer or $0.85 \% \mathrm{NaCl}$ solution containing $0.025 \%$ serum albumin. Phosphate buffer (M/15) caused more ${ }^{32} \mathrm{P}$ to be released from the cocci in the first $2 \mathrm{hr}$ than albumin saline (13\% compared with $1 \%$ ). Only $1 \cdot 6-1 \cdot 8 \%$ of the ${ }^{32} \mathrm{P}$ in cocci was released into human serum during this period. Phosphate exchange with the external medium accounted for some of the release of ${ }^{32} \mathrm{P}$ as indicated by increased ${ }^{32} \mathrm{P}$ in the presence of $\mathrm{PO}_{4}$.

The phosphate buffer in which cocci had been suspended was dialysed and treated with barium acetate solution at $\mathrm{pH} \mathbf{7 \cdot 3}$ to discover how much ${ }^{32} \mathrm{P}$ was present in the form of orthophosphate. Dialysis showed that only a proportion of the ${ }^{32} \mathrm{P}$ was diffusible; the amount diffusible varied with the experiment from about90 to $50 \%$. Precipitation of the phosphate buffer with barium acetate showed that the ${ }^{32} \mathrm{PO}_{4}$ released also varied in a similar way. Precipitation figures for ${ }^{32} \mathrm{PO}_{4}$ were usually 5-10\% higher than the dialysis figure, which would indicate the presence of other

\section{Table 4. The effect of the specific activity of growth medium on the release of} ${ }^{32} \mathrm{P}$ from labelled cocci into $\mathrm{M} / 15 \mathrm{PO}_{4}$ buffer, $p \mathrm{H} \mathbf{7 \cdot 2}$

Cocci were grown in broth containing $33 \mu \mathrm{g}$. $\mathrm{PO}_{4} / \mathrm{ml}$. with ${ }^{\text {s2 }} \mathbf{P O}_{4}$, washed three times and resuspended in non-radioactive buffer.

\begin{tabular}{|c|c|c|}
\hline \multirow[t]{2}{*}{$\begin{array}{l}\text { Specific } \\
\text { activity of } \\
\text { the culture } \\
\text { medium } \\
(\mu \mathrm{c} . / \mathrm{mg} .)\end{array}$} & \multicolumn{2}{|c|}{${ }^{32} \mathbf{P}$ released ( $\%$ total) after } \\
\hline & $1 \mathbf{h r}$ & $24 \mathrm{hr}$ \\
\hline $5 \cdot 8$ & $16 \cdot 0$ & 一 \\
\hline 0.58 & $24 \cdot 0$ & $57 \cdot 0$ \\
\hline $0 \cdot 13$ & $23 \cdot 0$ & $49 \cdot 0$ \\
\hline $0 \cdot 0003$ & $21 \cdot 0$ & $57 \cdot 0$ \\
\hline
\end{tabular}

materials in the $\mathrm{PO}_{4}$ buffer which reacted similarly to $\mathrm{PO}_{4}$ with barium acetate but had a high molecular weight. These results indicated that orthophosphate and other P-containing compounds were released from cocci into phosphate buffer, but that the amount of non-orthophosphate-P was variable. When cocci were suspended in an albumin-saline solution the proportion of dialysable ${ }^{32} \mathrm{P}$ released was lower than in phosphate buffer, 10-11\% compared with 50-90\%. Solutions which contained glucose and released ${ }^{32} \mathrm{P}$ were Nesslerized after digestion with sulphuric acid and potassium persulphate to test for the release of intracellular $\mathbf{N}$ as well as ${ }^{32} \mathbf{P}$. All solutions contained about $30 \mu \mathrm{g}$. $\mathrm{N} / \mathrm{ml}$, , whether glucose was present with phosphate buffer or not.

Mitchell \& Moyle (1953) found that the movement of ${ }^{32} \mathrm{PO}_{4}$ into the medium ceased when the cocci were respiring on glucose added to a buffer solution. In these 
experiments the addition of glucose to the phosphate buffer solution did not prevent the outward movement of $\mathrm{PO}_{4}$.

The simultaneous release of ${ }^{32} \mathrm{PO}_{4}$ and substances absorbing light at $260 \mathrm{~m} \mu$ from Staphylococcus aureus treated with CTAB has been described by Salton (1951). Hancock (1958) showed that these substances were purines and pyrimidines and their corresponding nucleosides and nucleotides. Amino acids and phosphorus were also released from cells. A similar release of nitrogenous material with ${ }^{{ }^{22}} \mathrm{PO}_{4}$ occurred when cocci were suspended in phosphate buffer.

The effect of the specific activity of cocci on the release of ${ }^{32} \mathrm{P}$ compounds into $\mathrm{PO}_{4}$ buffer $\mathrm{M} / 15$ was investigated. The amount of radioactivity in the coccus did not appear to influence the amount of ${ }^{32} \mathrm{P}$ released (Table 4).

The effect of total amount of $\mathbf{P}$ a coccus contained on the release of phosphorus was determined (Table 5). Analysis of the variance shows that the $P$ content of the coccus had no significant effect on the amounts of ${ }^{32} \mathrm{P}$ released.

\section{Table 5. The effect of coccal phosphorus content on the release of ${ }^{32} P$ into phosphate buffer}

Cocci were grown in broth with 1-10 $\mu \mathrm{c}$. ${ }^{32} \mathrm{PO}_{4} / \mathrm{ml}$., washed and resuspended in $\mathrm{M} / 15$ $\mathrm{PO}_{4}$ buffer $\mathrm{pH} \mathrm{7.2}$. The ${ }^{32} \mathrm{P}$ level in the cocci increased with increasing ${ }^{82} \mathrm{PO}_{4} / \mathrm{ml}$. in the broth (Fig. 1). Each result was calculated from five experiments.

${ }^{32} \mathrm{O}_{4}$ in broth
$(\mu \mathrm{g} . / \mathrm{ml}$.
33
100
400

Total ${ }^{32} \mathbf{P}$ released

in $1 \mathrm{hr}$

(\%: mean and s.E.M.)

$$
\begin{aligned}
& 26 \cdot 5 \pm 12 \cdot 8 \\
& 24 \cdot 5 \pm 10 \cdot 9 \\
& 35 \pm 15 \cdot 7
\end{aligned}
$$

Variance estimate, $\boldsymbol{F}=\mathbf{0 \cdot 6 3 1}$

\section{(b) Release of ${ }^{32 P}$ from dividing cocci}

Cocci labelled with ${ }^{32} \mathrm{P}$ by growing them in broth containing $150-200 \mu \mathrm{c} .{ }^{32} \mathrm{P} / \mathrm{ml}$. and $33 \mu \mathrm{g} . \mathrm{PO}_{4} / \mathrm{ml}$. were inoculated into nutrient broth which had not been dephosphated. After washing with albumin-saline solution the distribution of ${ }^{32} \mathbf{P}$ between the cocci and the medium was measured. $80-81 \%$ of the ${ }^{32} \mathrm{P}$ originally present in the cells appeared in the medium after overnight growth at $37^{\circ}$. Only $20-21 \%$ of the ${ }^{32} \mathbf{P}$ released was diffusible on dialysis. Analysis of the ${ }^{32} \mathbf{P}$ distribution after growth of the labelled inoculum in the unlabelled medium showed small changes had occurred in the relative amounts of ${ }^{32} \mathrm{P}$ in each fraction. The hot TCA fraction contained less ${ }^{32} \mathrm{P}, 41 \%$ compared with $54 \%$ in the original inoculum; the cold TCA fraction contained $\mathbf{8 5} \%$ after growth; the original inoculum contained $38 \%$. The content of the DNA fraction increased after growth from 4.7 to $9 \%$; the phosphoprotein and lipid fraction was $9 \cdot 0 \%$ after growth and $2.6 \%$ in the original inoculum. The organic fraction was most severely depleted.

Autoradiography of labelled cocci. Good autoradiographs of Staphylococcus aureus labelled with ${ }^{32} \mathrm{P}$ in the skin of the mouse were obtained when AR 10 (Kodak) stripping film was exposed to cocci containing $3 \cdot 3 \times 10^{-8} \mu \mathrm{c}$./coccus for 3 days. 


\section{DISCUSSION}

Staphylococcus aureus may be satisfactorily labelled with ${ }^{32} \mathrm{P}$ for autoradiographic purposes and tracer experiments in animals by growing it in broth containing 150-200 $\mu$ c. ${ }^{32} \mathrm{P} / \mathrm{ml}$. and $33 \mu \mathrm{g}$. orthophosphate $/ \mathrm{ml}$. The specific activity of the bacteria was about $2 \cdot 0-3.5 \times 10^{-8} \mu \mathrm{c}$./coccus. It is not possible to label the cocci more heavily without severely decreasing their growth and viability. Cocci labelled in this way are as virulent in mice as non-labelled ones. These findings are in agreement with Stonier's (1956) Agrobacterium tumefaciens labelled with ${ }^{32} \mathbf{P}$. He found a similar specific activity compatible with normal viability in bacteria grown on a defined medium. It would appear that in both $S$. aureus and A. tumefaciens the specific activity of the organism decides whether they will survive. The level of radioactivity per ml. (150-200 $\mu \mathrm{c}$.) did not affect growth when sufficient non-radioactive phosphate was present (about $67 \mu \mathrm{g} . / \mathrm{ml}$.); metabolic disturbance was probably caused by the decay of ${ }^{32} \mathrm{P}$ to ${ }^{32} \mathrm{~S}$.

The interrelation of phosphate in the growth medium and phosphorus in fungi was previously recorded by Rennerfelt (1934), who worked with Aspergillus niger. As the phosphate concentration of the medium was increased from $25 \mu \mathrm{g} . / \mathrm{ml}$. to $750 \mu \mathrm{g} . / \mathrm{ml}$. the phosphorus in the mycelium increased almost linearly. Maximum uptake of phosphate from the medium was $20 \%$, decreasing to $17 \%$ when maximal amounts of phosphate were present. The relationship between phosphorus in the cells and phosphate in the medium is very similar for Staphylococcus aureus. The maximal amount of phosphate in the medium is about half the maximal amount for $A$. niger and the percentage uptake is also less.

Park \& Johnson (1949) analysed Staphylococcus aureus and found that $60 \%$ of the $\mathbf{P}$ was present as inorganic phosphate, $5 \%$ as labile phosphate and $30-\mathbf{3 5} \%$ as stable phosphate. This analysis is similar to the one for P-rich cocci in these experiments. The cold TCA fraction contained $73-78 \%$ of coccal ${ }^{32} \mathrm{P}, 80 \%$ of which gave an orthophosphate reaction by forming an insoluble $\mathrm{Ba}$ salt at $\mathrm{pH} 7 \cdot 4$. Polyphosphate has not been described in $S$. aureus but has been found in other organisms, in Corynebacterium diphtheriae by Sall et al. (1958), in Mycobacteria by Winder \& Denneny (1957) and in Azotobacter vinelandii by Zaitseva, Belozerskii \& Novozhilova (1960). In these organisms it serves as a reservoir of $P$ for RNA synthesis. In $S$. aureus part of the cold TCA and hot TCA fractions formed an insoluble Ba salt at $\mathrm{pH} 4$, a reaction which is typical of metaphosphate. However, $S$. aureus contains large amounts of teichoic acid (Archibald, Armstrong \& Baddiley, 1961), and if this compound forms an acid-insoluble $\mathrm{Ba}$ salt it might have been confused with metaphosphate.

The release of non-diffusible ${ }^{32} \mathrm{P}$ compounds on dialysis into phosphate buffer from Staphylococcus aureus may have been the result of osmotically fragile cells autolysing (Mitchell \& Moyle, 1957). This release of large molecular weight materials may also be the result of degradation of RNA and other phosphorus-containing compounds present in non-viable cocci. The release from dividing cocci might be the result of an exchange reaction, autolysis and the degradation of P-containing compounds. The relatively low amounts of ${ }^{32} \mathrm{PO}_{4}$ in the broth, about $20 \%$ compared with the original content of the cocci, about $35 \%$, suggests that some of the released material might have been re-utilized by the growing population. If this has occurred the cocci 
utilizing the ${ }^{32} \mathrm{P}$ would have a higher proportion of ${ }^{32} \mathrm{P}$ in the cold TCA fraction and less in the hot TCA fraction, since the broth contained about $700 \mu \mathrm{g}$. $\mathrm{PO}_{4} / \mathrm{ml}$. The population would then contain less ${ }^{32} \mathrm{P}$ in the hot TCA fraction than the original inoculum. This change did take place but may also be explained on the basis of greater dilution of the hot TCA fraction with ${ }^{32} \mathrm{P}$ taken from the medium and the movement of ${ }^{32} \mathbf{P}$ from the organic fraction to compounds with a low $\mathbf{P}$ turnover. Possibly several factors caused a depletion of ${ }^{32} \mathrm{P}$ in the hot TCA fraction after growth in an unlabelled medium. Stonier (1960) found that the release of ${ }^{32} \mathrm{P}$ from Agrobacterium tumefaciens was caused by a lytic phage. No such phage was demonstrated in this strain of $S$. aureus.

Elek (1959) described the formation of extracellular compounds by Staphylococcus aureus: some of the ${ }^{32} \mathrm{P}$ appearing in the growth medium could be present in the extracellular enzymes and proteins excreted as the result of non-autolytic processes.

The author wishes to thank Dr S. Fisher (Kanematsu Institute) for bacterial counts and turbidity measurements and Mr A. Negrin for phosphate estimations.

\section{REFERENCES}

Albaum, H. G., Hodge, H. C., Hutchinson, G. E., Lardy, H. A. \& Sacks, J. (1952). The Biology of Phosphorus. Michigan: Michigan State Press.

Archibald, A. R., Armstrong, J. J., Baddiley, J. \& Hay, J. B. (1961). Teichoic acids and the structure of bacterial walls. Nature, Lond. 191, 570.

Briggs, A. P. (1922). A modification of the Bell-Doisy phosphate method. J. biol. Chem. 53, 13.

EuEk, S. D. (1959). Staphylococcus pyogenes and its Relation to Disease, p. 219. Edinburgh and London: E. S. Livingstone Ltd.

ELY, J. D. (1942). Distribution in the rate of injected radio-activated bacteria. $J$. Franklin Inst. 234, 500.

HANCOCK, R. (1958). The intracellular amino acids of Staphylococcus aureus. Release and analysis. Biochim. biophys. Acta, 28, 402.

Miles, A. A. \& MisRa, S. S. (1938). Estimation of the bactericidal power of blood. $J$. Hyg., Camb. 38, 732.

Mitcheld, P. \& MoYle, J. (1953). Paths of phosphate transfer in Micrococcus pyogenes: phosphate turnover in nucleic acids and other fractions. J. gen. Microbiol. 9, 257.

Mitchell, P. \& MoYLe, J. (1957). Autolytic release and osmotic properties of protoplasts from Staphylococcus aureus. J. gen. Microbiol. 16, 184.

Mudd, S., Yoshida, A. \& KoIke, M. (1958). Polyphosphate as accumulator of phosphorus and energy. J. Bact. 75, 224.

Park, J. T. \& Hancock, R. (1960). A fractionation procedure for studies of the synthesis of cell-wall mucopeptide and of other polymers in cells of Staphylococcus aureus. J. gen. Microbiol. 22, 249.

Park, J. T. \& Johnson, M. J. (1949). Accumulation of labile phosphate in Staphylococcus aureus grown in the presence of penicillin. J. biol. Chem. 179, 585 .

RenNerfelt, E. (1934). Untersuchungen über die Salzaufnahme bei Aspergillus niger. Planta, 22, 221.

Sall, T., Mudd, S., Takagi Atsushi (1958). Polyphosphate accumulation and utilization as related to synchronized cell division of Corynebacterium diphtheriae. J. Bact. 76, 640 .

SALton, M. R. J. (1951). The absorption of cetyltrimethylammonium bromide by bacteria, its action in releasing cellular constituents and its bactericidal effects. J. gen. Microbiol. $5,391$.

Sandedt, E. B. (1953). Colorimetric Determination of Traces of Metals. New York: Interscience Publishers. 
Stonier, T. (1956). Labelling crown gall bacteria with ${ }^{32} \mathrm{P}$ for radioautography. J. Bact. $72,259$.

Stonier, T. (1960). Agrobacterium tumefaciens. Conn. 1. Release of ${ }^{32} \mathrm{P}$ and ${ }^{35} \mathrm{~S}$ by labelled bacteria in vitro. J. Bact. 79, 880.

Thorbecke, G. J. \& Benacerraf, B. (1959). Some histological and functional aspects of lymphoid tissue in germ free animals. II. Studies on phagocytosis 'in vivo'. Ann. N.Y. Acad. Sci. 78, 247.

Winder, F. G. \& Denneny, J. M. (1957). The metabolism of inorganic polyphosphate in Mycobacteria. J. gen. Microbiol. 17, 573.

Zaitseva, G. N., Belozerskit, A. N. \& Novozhilova, L. P. (1960). A study of the phosphorus compounds in the development of Azotobacter vinelandii using ${ }^{32} \mathrm{P}$. Biokimiya, 25, 198. 